\title{
Determinants of Absorptive Capacity: a systematic literature review
}

Naijela Janaina Costa Silveira ${ }^{1}$. Paulista University, Jundiaí, São Paulo, Brazil.

Diogo Ferraz ${ }^{2}$. Federal University of Ouro Preto, Mariana, Minas Gerais, Brazil.

Diego Scarpa de Mello3. Federal University of São Carlos, São Carlos, São Paulo, Brazil.

Eduardo Polloni-Silva ${ }^{4}$. Federal University of São Carlos, São Carlos, São Paulo, Brazil.

Daisy Aparecida do Nascimento Rebelatto ${ }^{5}$. University of São Paulo, São Carlos, São Paulo, Brazil.

Herick Fernando Moralles ${ }^{6}$. Federal University of São Carlos, São Carlos, São Paulo, Brazil.

\section{RESUMO}

Objetivo - Apresentar uma revisão da literatura sobre os determinantes da Capacidade de Absorção (CA), que possibilita os spillovers de produtividade oriundos dos Investimentos Diretos Estrangeiros (IDE) em países desenvolvidos e em desenvolvimento.

Arcabouço teórico - Esta pesquisa baseia-se na literatura de que, antes de se beneficiar de spillovers, empresas precisam de um nível mínimo de conhecimento e de capacidades.

Método - Uma Revisão Sistemática de Literatura (RSL) dos estudos empíricos sobre CA e spillovers de produtividade é apresentada. No total, 60 artigos foram analisados.

Resultados - A RSL revelou que capital humano e investimentos em P\&D são os determinantes mais citados. P\&D é particularmente importante para países em desenvolvimento.

Implicações práticas e sociais - Políticas públicas voltadas ao desenvolvimento do P\&D podem ser estratégias facilitadoras de spillovers de produtividade em países em desenvolvimento.

Originalidade - Este artigo analisa os determinantes da CA enquanto considera como tanto os países desenvolvidos e em desenvolvimentos podem se beneficiar do IDE, o que é de suma importância considerando o crescimento do IDE em países em desenvolvimento.

Palavras-chave - Investimento Direto Estrangeiro. Produtividade. Spillover.

\section{ABSTRACT}

Purpose - To conduct a literature review on the determinants of Absorptive Capacity (AC), which allows for productivity spillovers from Foreign Direct Investment (FDI) in developed and developing countries.

Theoretical framework - This study is based on the literature indicating that before benefiting from spillovers, companies need a certain level of knowledge and expertise.

Design/methodology/approach - A Systematic Literature Review (SLR) of empirical studies on AC and productivity spillovers is presented. A total of 60 articles were reviewed.

Findings - The SLR revealed that human capital and $R \& D$ investments are the most frequently cited determinants of AC. $R \& D$ is especially important for developing countries.

Research, Practical \& Social implications - Public policies targeting R\&D development may be a valuable strategy to facilitate productivity spillovers in developing countries.

Originality/value - This paper analyzes the determinants of AC while verifying how both developed and developing countries can benefit from FDI, which is of great importance considering the growth of FDI in developing countries. Keywords - Foreign Direct Investment. Productivity. Spillover.

1.Rua Orlando Signorelli 425 apt 114-B. Hortolândia, SP. Zip: 13185340. naijela.silveira@docente.unip.br, https://orcid.org/0000-0003-1398-2384; 2. diogoferraz@alumni.usp.br, https://orcid.org/0000-0003-4037-7171; 3. dscarpa.mello@ gmail.com; https://orcid.org/0000-0002-5193-7106; 4eduardopolloni1@ gmail.com; https://orcid.org/0000-00015141-2433; 5. daisy@usp.br; https://orcid.org/0000-0003-0611-1492; 6. herickmoralles@ dep.ufscar.br; https://orcid.org/00000001-5141-2433.

SILVEIRA, N.J.C.; FERRAZ, D.; MELLO, D.S.; SILVA, E.P.; REBELATTO, D.A.N.; MORALLES, H.F. Determinants of Absorptive Capacity: a systematic literature review. GEPROS. Gestão da Produção, Operações e Sistemas, v.16, n 2, p. 122 $-152,2021$.

DOI: http://dx.doi.org/10.15675/gepros.v16i2.2762 


\section{INTRODUCTION}

Absorptive Capacity (AC) is one of the most influential concepts in management literature. AC was first introduced by Cohen and Levinthal (1989) and then developed by Zahra and George (2002) in the context of learning and innovation of a company, and is currently a keyword for a variety of strategies, administrative routines, and learning processes that influence a company's ability to exploit the external knowledge needed to build other organizational capacities (TODOROVA; DURISIN, 2007; ZAHRA; GEORGE, 2002).

Cohen and Levinthal (1990) and Malaguerra (2014) define AC as the ability to recognize, assimilate, and apply new information for commercial purposes. Lapan and Bardhan (1973) point out that companies need a certain level of AC before benefiting from technologies developed by other companies. Malaguerra (2014) states that AC is important in all countries, especially for countries that seek to approach the technological frontier.

Most studies typically measure AC with $\mathrm{R} \& \mathrm{D}$ proxies, therefore ignoring other dimensions and their implications for different organizational results. Thus, the variables do not establish a time horizon or frequency of activities and carry an R\&D bias, which is not the only possibility of using external knowledge. Yet, they establish multiple indicators for capacity based on processes/routines, and the measures are benchmarked, qualifying the level of $\mathrm{AC}$.

Accordingly, the necessity to use knowledge and technologies from external sources is increasing, as they become a vital component of national innovation processes (GRIMPE; SOFKA, 2008; KING; LAKHANI, 2011), allowing companies to increase their resource base and adapt to the market (ZAHRA; GEORGE, 2002). Therefore, Smeets (2008) emphasizes that $\mathrm{AC}$ determines the intensity and signal of spillovers.

Lapan and Bardhan (1973) argue that companies need a specific AC before they benefit from other companies' technologies. Cohen and Levinthal (1989) argue that increasing R\&D activity increases efficiency indirectly by accelerating the assimilation of technologies developed elsewhere.

Amidst this debate, the ability to attract Foreign Direct Investment (FDI), according to Sari et al. (2016), can bring immense benefits to the host country. FDI refers to an investment that seeks to acquire a lasting interest in a company whose exploration takes place in a foreign country, and the investor intends to influence the company's management (IMF, 1998). In 
sum, these incoming multinational corporations provide direct and indirect benefits to the host economy. According to Barro and Sala-i-Martin (1997), FDI can positively contribute to the convergence of developed and developing countries, and these investments particularly increase imitation activities in developing countries. The direct benefits of foreign affiliates can result in new investments, productive capacity, demand for labor, demand for intermediate goods, and sometimes exports that stimulate national income or economic growth, therefore providing new opportunities while increasing tributary revenues (TAKII, 2005). Therefore, FDI is perceived as a knowledge source for the economy, and, in many cases, has been an essential element in economic development strategies. Thus, it is necessary to analyze the determinants of AC to maximize the effects of spillover from FDI on the productivity of nations.

In this context, this article aims to perform a Systematic Literature Review (SRL) on the determinants of $\mathrm{AC}$ in developed and developing countries aiming towards productivity spillovers deriving from FDI. It is noteworthy that FDI has increased significantly for developing countries over the past two decades. This significantly increased importance has received particular attention in discovering the relationship between FDI and economic growth in the host country. In this way, finding out the factors that impact the incoming FDI volume in a given economy and the effects of that capital on the receiving nation's economic growth is critical since these impacts may be conditioned to the host country.

The results obtained have direct implications for the future formulation of industrial policies to attract FDI and programs encouraging the competitiveness of national industries by increasing their total productivity. Specifically, the now identified determinants of AC will serve as targets to be achieved prior to a possible FDI attraction policy to enhance positive productivity spillovers, and to avoid negative spillovers relative to competition for the domestic industry.

This study is organized into three sections besides this introduction. Section 2 presents the Systematic Literature Review (SLR) technique. Section 3 brings the results and discussions of this paper. Finally, section 4 presents the concluding remarks.

\section{METHODOLOGICAL PROCEDURES}

A systematic literature review provides a methodical, explicit, and replicable synthesis of a given topic (REIM et al., 2015). SLR is a vital research endeavor by itself and not merely 
a review of previous writings. It responds to specific research questions, and is a method that locates existing studies, selects and evaluates contributions, analyses and synthesizes data, and reports the evidence in a way that allows reasonably clear conclusions to be reached about what is and is not known (DENYER; TRANFELD, 2009).

We applied the Systematic Literature Review (SLR) technique to analyze the main determinants that influence the AC and its impact on productivity. We used the Scopus and Web of Science databases to represent the most important studies in this research field. Note that these databases were chosen as they have the most extensive global collections of articles and publishers, and have been used in several other systematic literature reviews. The next subsection presents the literature review procedure Knowledge Development Process Constructivist (ProKnow-C) applied for the articles' selection and analysis.

\subsection{ProKnow-C}

For the selection of scientific publications, the Knowledge Development ProcessConstructivist (ProKnow-C), developed by the Laboratory of Multicriteria Decision Support Methodologies (LabMCDA), Federal University of Santa Catarina (UFSC), was used as an intervention tool. ProKnow-C has already been used in other studies that have investigated a multitude of topics (NUERNBERG et al., 2016; CARDOSO et al., 2016; AFONSO et al., 2012; LACERDA et al., 2012). Lacerda et al., (2012), Ensslin et al., (2012) and Rosa et al., (2012) claim that the identification of relevant articles that generate knowledge and support the conduct of scientific research has become very complex given the abundance of information available.

ProKnow-C has the main goal of providing knowledge about a fragment of scientific literature. The instrument leads the researcher (i) to select a Bibliographic Portfolio (PB) of scientific and relevant articles that answer the research topic; (ii) to perform an investigation and an analysis of the characteristics of this PB (i.e., bibliometric analysis); (iii) to critically reflect on the position of the studies, based on the theoretical affiliation established by the researcher (i.e., systematic analysis); and (iv) to point out the gaps and opportunities of future research, based on the knowledge generated in the previous two stages. All the steps require the active participation of the researcher for its accomplishment. Thus, the constructivist process occurs and evolves based on the interests and delimitations established by the 
researcher (SILVA et al., 2014; DUTRA et al., 2015). Therefore, the process is composed of four stages, as shown in Figure 1.

Figure 1 - Stages of the ProKnow-C methodology

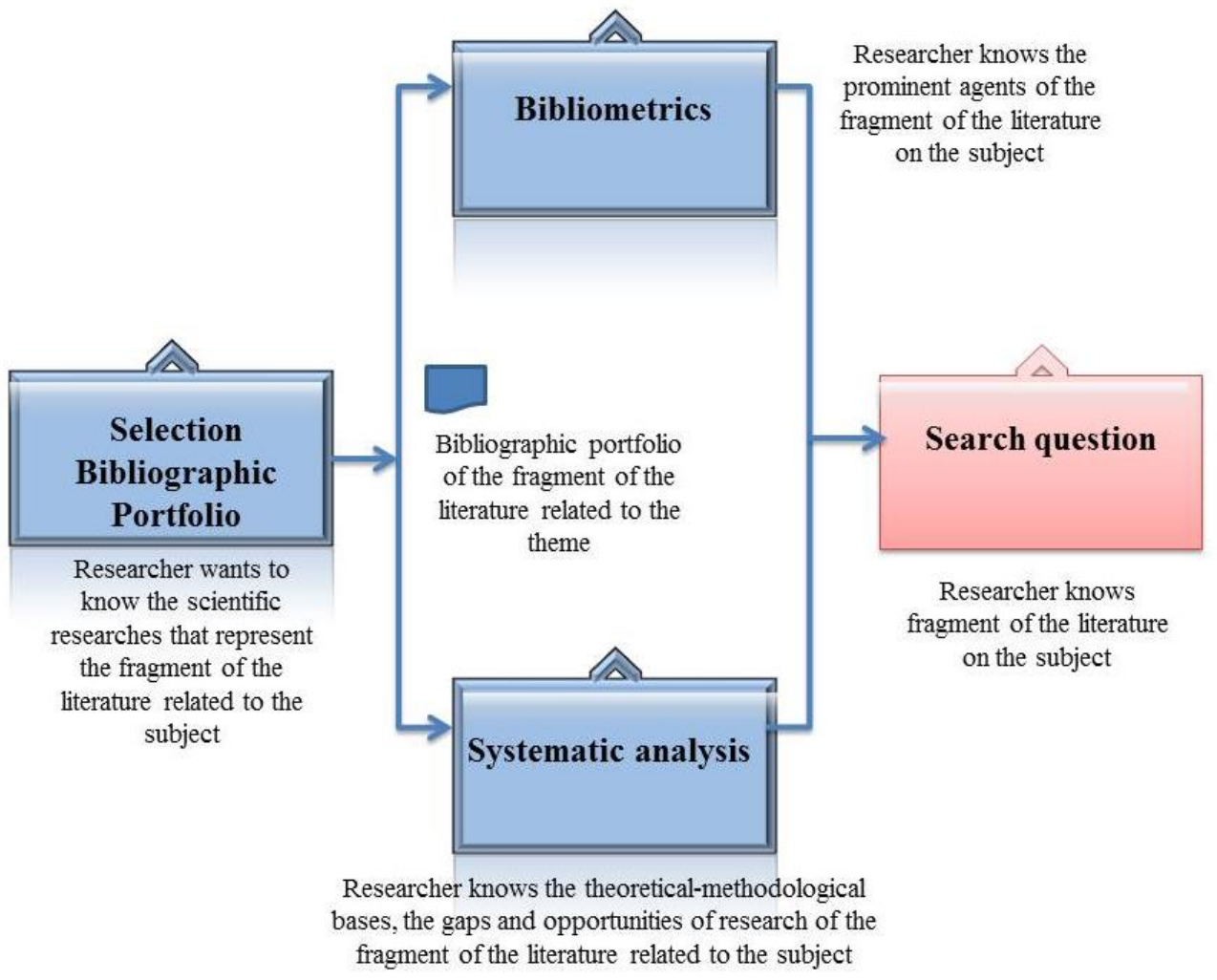

Source: the authors (2020).

In order to reach the objective of the research, only the first 3 main stages (in blue) of the ProKnow-C tool were applied since the objective of this review is not to analyze points that have not yet been studied by authors but to analyze the determinants of AC considering the studies already carried out. Thus, to carry out the first three stages of the methodology, each stage was broken down into steps.

Stage 1 - Selection of the Bibliographic Portfolio

- Step 1: Refine the main keywords through a network of keyword co-occurrence;

- Step 2: Evaluation of articles published in the main databases, using a set of preestablished keywords.

\section{Stage 2 - Bibliometrics}

- Step 1: Screening of articles found by reading their titles and abstracts (filter); 
- Step 2: Selection of publications for in-depth analysis;

- Step 3: Building the profile of the scientific production of each selected article, identifying the main research strategies.

Stage 3- Systematic Analysis

- Step 1: Analysis of the scope of each selected article;

- Step 2: Selection of determinants. In this case, these are the variables cited as capable of affecting the $\mathrm{AC}$, and therefore were selected as proxies of the AC.

\section{SYSTEMATIC LITERATURE REVIEW}

This section represents the methodological characterization of the ProKnow-C that was applied for the selection and analysis of articles.

\subsection{Methodological characterization}

Research based on Production Engineering usually begins with selecting scientific documents for the composition of the theoretical foundation and to identify the gaps in the literature (CAUCHICK et al., 2010). Faced with the number of scientific articles currently available, one of the researcher's difficulties is to find out which studies are relevant for the field.

This research is characterized as a qualitative and quantitative approach (GREENER, 2008; CRESWELL, 2007). Our study is considered qualitative because it comprises procedures to obtain a portfolio of scientific articles. This analysis is based on the perception of the researchers who lead the study. Complementary, this study is quantitative because it seeks identifiable and observable objective facts, through the use and manipulation of numbers, both regarding the procedures pertinent to the identification of the bibliographic portfolio (for example, to analyze the scientific recognition of the articles) and the bibliometric analysis of this portfolio.

From this perspective, this research is inductive because it aims to generate knowledge - a theoretical framework for scientific research - from the identification of studies closely related to the determinants of AC (GREENER, 2008). As for the technical procedures, the research is characterized as bibliographical (RICHARDSON; PERES, 1999), and the data sources are secondary since all the information was obtained from scientific publications. 


\subsection{Selection Bibliographic Portfolio}

In this section, we present the bibliographic portfolio to achieve the relevant articles about AC. Moreover, we describe the number of studies found using the bibliographic portfolio.

\subsubsection{Selection bank gross articles}

The selection of studies is a crucial step to achieve a reliable database which represents the most important studies in a research field. In this sense, we used a protocol with four keywords applied to two research databases. Moreover, we limited our analysis to documents written as article type (which is the most common way to transmit knowledge within the scientific community) and in English. We did not limit the number of analyzed years to guarantee that all articles in this research field appear in our database. Our search shows that 960 articles are available. Table 1 summarizes our protocol.

Table 1 - ProKnow-C Phase - Selection of the gross articles bank

\begin{tabular}{ll}
\hline ProKnow-C Phase & International Portfolio \\
\hline Gross Items Bank Selection & \\
Consulted databases & Scopus and Web of Science \\
Keywords & $\begin{array}{l}\text { Productivity AND Absorptive Capacity } \\
\text { knowledge Spillover AND Absorptive Capacity }\end{array}$ \\
& Type of publication: Journal article \\
Delimitation & English language \\
& Time limit: not limited \\
Date of consultation & March 2018 \\
Results & 960 articles \\
\hline
\end{tabular}

Source: the authors (2020).

\subsubsection{Article bank filtering}

For the filtering stage, an SLR protocol was generated, which is presented in Appendix A with the main information about the research. The protocol includes the strategies used for searching and selecting primary studies, the criteria and procedures for selecting the studies, and the process of study selection. Table 2 shows the number of papers selected in the databases in detail. 
Table 2 - ProKnow-C Phase - Filtering articles

\begin{tabular}{lcc}
\hline Criteria for analysis & Scopus & Web of Science \\
\hline Articles identified with keywords & 219 & 741 \\
Selected papers after summary analysis & 55 & 40 \\
Number of papers shared in both databases & \multicolumn{2}{c}{35} \\
Total articles reviewed & \multicolumn{2}{c}{60} \\
\hline
\end{tabular}

Source: the authors (2020).

From the selected articles, $18.33 \%$ (11 articles) of the sample presented a nationwide study population, encompassing several countries (ALDIERI et al., 2018; FOSTERMCGREGOR et al., 2017; KHORDAGUI; SALEH, 2016; HUEBLER et al., 2016; KRAMMER, 2010; KELLER, 2010). These articles will be analyzed separately since the study population of countries is our focus of study.

The articles previously mentioned used the panel data structure. Of the entire sample, 50 articles $(83.3 \%)$ used panel data, 5 articles $(8.3 \%)$ cross-section data, and 5 articles $(8.3 \%)$ were not mentioned, including this one literature review.

Of the sample, 31.6\% (19 articles) analyzed developed countries, 56.6\% (34 articles) focused on emerging countries, and $11.6 \%$ ( 7 articles) did not identify the study population, were literature reviews, or worked with several non-explicit countries or regions.

\subsubsection{Test of the representativeness of the bibliographic portfolio}

The number of citations is a useful tool for identifying the most important studies. However, recent articles did not have enough time to become prominent articles. Table 3 shows the fifteen most cited articles among the 60 selected, along with the number of citations in the Scopus and Web of Science databases in March 2018.

Table 3 - Fifteen articles most cited in the literature.

\begin{tabular}{lcc}
\hline Author(s)/Year & Citations in Scopus & Citation in Web of Science \\
\hline Girma (2005) & 182 & 149 \\
Zhang et al. $(2010)$ & 116 & 109 \\
Barrios and Strobl (2002) & 58 & 47 \\
Keller (2010) & 49 & $* *$ \\
Marcin (2008) & 39 & 19 \\
Ahmed (2012) & 28 & 15 \\
Higoacuten and $\quad$ Vasilakos & 22 & 4 \\
$(2011)$ & 16 & $* *$ \\
Krammer (2010) & &
\end{tabular}




\begin{tabular}{|c|c|c|}
\hline Caragliu and Nijkamp (2012) & 20 & 18 \\
\hline Anwar and Nguyen (2014) & 17 & $* *$ \\
\hline Miguelez and Moreno (2015) & 15 & 12 \\
\hline Augier et al. (2013) & 14 & 12 \\
\hline Qi et al (2009) & 13 & 10 \\
\hline Sánchez-Sellero et al. (2014) & 11 & 11 \\
\hline Hamida (2013) & 10 & 8 \\
\hline
\end{tabular}

Source: the authors (2020).

Among the selected articles, the most cited were Girma (2005) and Zhang et al. (2010). Girma (2005) examined the relationship between AC and technology spillovers using enterprise-level data from the UK manufacturing industry. Zhang et al. (2010) analyzed the effect of the diversity of origins of FDI countries on domestic firms' productivity. It should be added that pioneering articles such as Barrios and Strobl (2002) and Marcin (2008) also show numerous citations. Figure 2 illustrates this result.

Figure 2 - Fifteen most cited articles in the literature

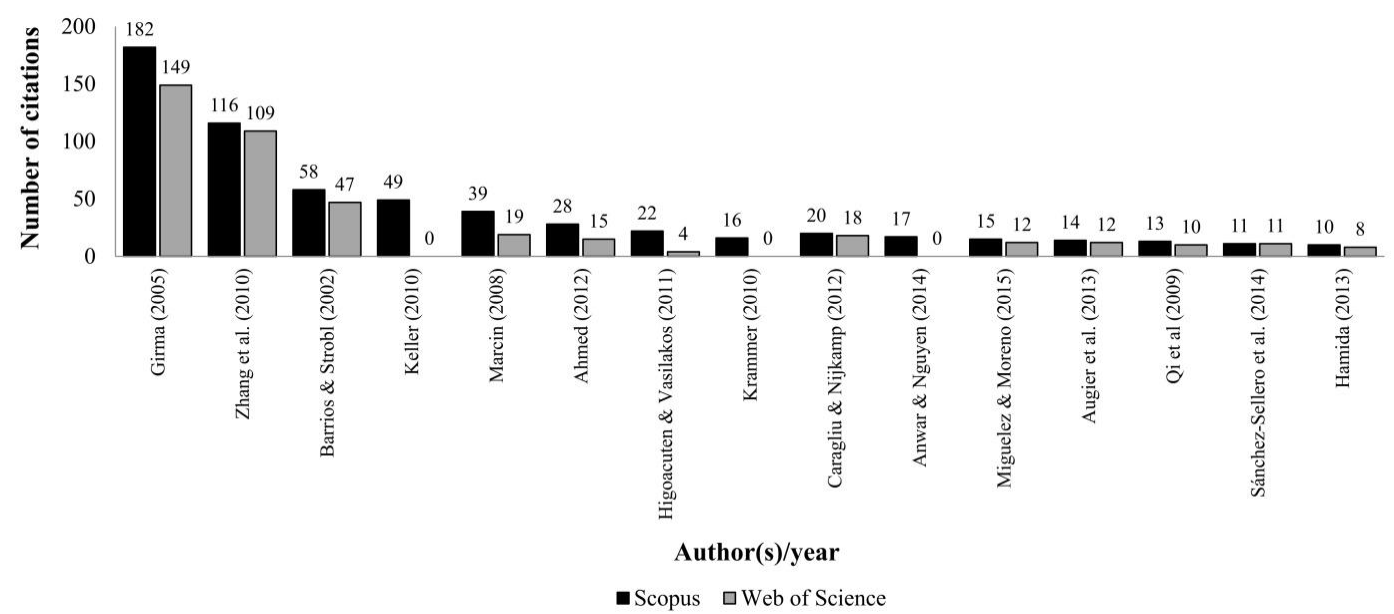

Source: the authors (2020).

In contrast, some recent studies bring new insights in this research field, such as Sánchez-Sellero et al. (2014) and Hamida (2013). Sánchez-Sellero et al. (2014) was found that R\&D activities increase the generation of new knowledge and the FDI absorptive capacity. Internal $R \& D$ activities have the most positive effect; outsourced activities have a negative impact. This explains the decision to outsource $R \& D$ for small innovations that 
require unspecified investments. In Hamida (2013), the results show that only local companies that have thoroughly invested in AC benefit from spillovers, mainly due to technology transfer. This benefit appears to occur both at the regional and external levels.

Girma (2005), the most cited, examined the relationship between AC and technology spillovers using company-level data from the UK manufacturing industry and used the threshold regression model, while Hamida (2013) used the regional FDI distribution to test regional and inter-regional spillovers, however the aim was to adapt the production function. Girma's differential was the use of the threshold model. Furthermore, the bibliometric analysis is an important tool to describe the studies under analysis. The next section brings some findings.

\subsection{Bibliometric portfolio analysis}

Bibliometry is characterized by the quantitative disclosure of a bibliographic portfolio's statistical data that aims to manage the information and the scientific knowledge of a specific subject through document counting (ENSSLIN et al., 2010). In this study, bibliometrics involve the analysis of journals, publications per year, and publications by geographic regions.

Figure 3 shows the degree of relevance of the journals in the bibliographic portfolio. In other terms, this analysis shows which journals stand out by the number of published articles. Seven international journals present a relevant number of publications. The Journal Economics of Innovation and New Technology stands out for 4 published articles (FOSTERMCGREGOR et al., 2017; BEHERA, 2017; BLOCH, 2013; LOPEZ-GARCIA; MONTERO, 2012), followed by the Research Policy journal with 3 published articles (QIU; LIU; GAO, 2017; LIANG, 2017; MIGUELEZ; MORENO, 2015).

The articles published on the Economics of Innovation and New Technology present studies that examine the occurrence of productivity spillovers from Foreign Direct Investment (FDI) as well as the role of AC in this process. Also, studies published on the Research Policy analyze how high CA regions make the most of external flows of knowledge and information through mobility and networks of inventors, as well as exploring how industrial links, resources and the location of domestic geographic companies affect the diffusion of technology brought about by FDI. 
Figure 3 - Relevance of journals

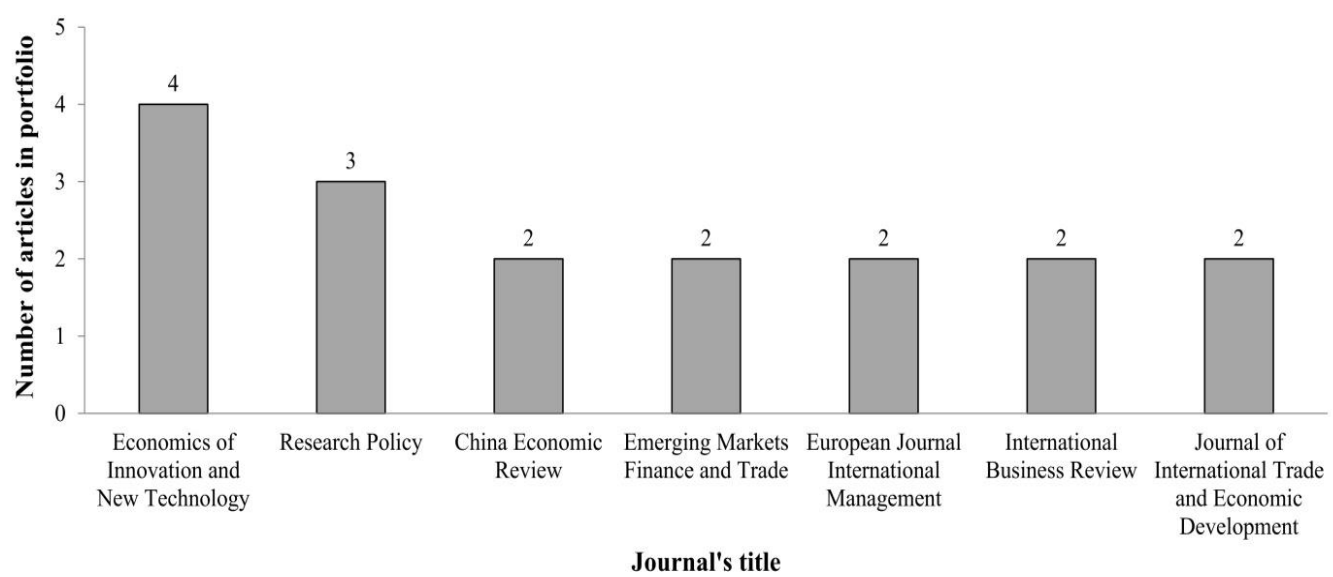

Source: the authors (2020).

It is noteworthy that some journals are specific for developing countries, such as China Economic Review and Emerging Markets Finance and Trade. This is a piece of evidence that the AC subject is an important approach to developing economies. Moreover, we found the European Journal International Management among journals with the most published articles in AC, revealing that this field is also relevant for developed economies.

Figure 4 shows the number of papers published in the bibliographic portfolio, highlighting the year 2017 with the highest number of publications. It is noteworthy that the year 2018 was not completed, given the possibility of increasing the number of the same publications. We found little variation in the number of publications between 2000 and 2009, which corresponds to only one study per year. In contrast, between 2010 and 2015, we found a higher number of publications on AC from 3 to 6 publications per year. More importantly, the years 2016-2017 highlight the growing attention that $\mathrm{AC}$ has been receiving by the research community. In 2016, 10 studies were published in this research field. Moreover, in 2017, 17 studies were published analyzing the AC approach. This finding reveals a larger number of studies in the last years, which confirms an upward curve in the number of publications. 
Figure 4 - Number of papers published per year

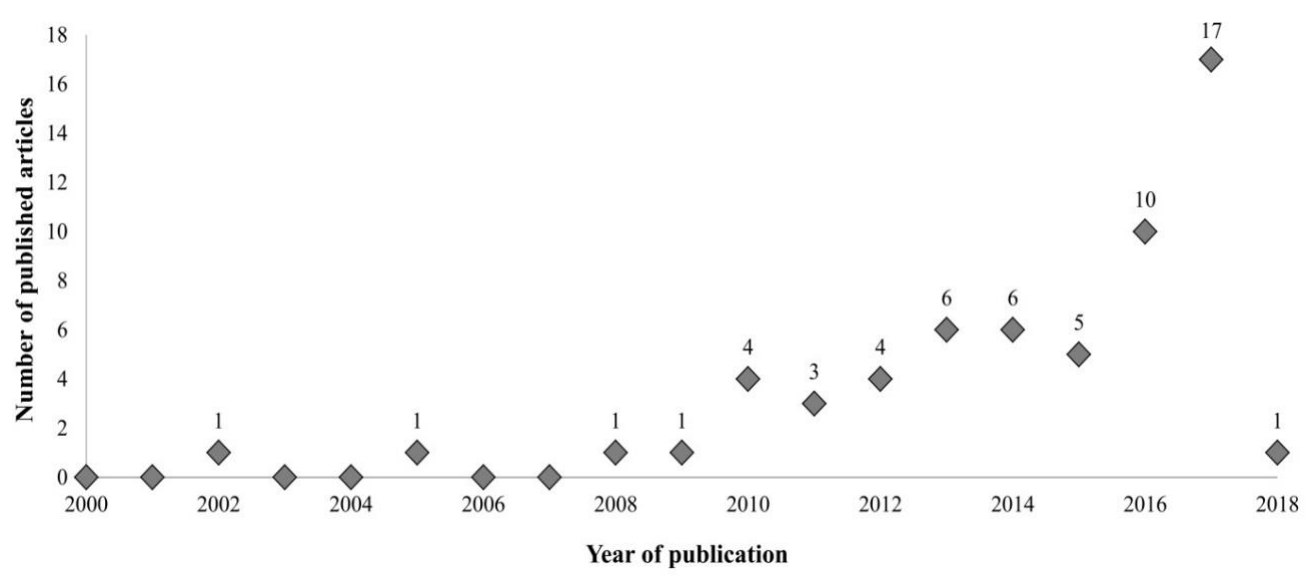

Source: the authors (2020).

Figure 5 reports the number of articles published by geographical region. Surprisingly, we found that $22,7 \%$ of the studies analyzed are from China. Other studies analyzed countries like Spain (13,6\%), Turkey $(9,1 \%)$, South Korea $(6,8 \%)$, the USA $(4,5 \%)$, Malaysia $(4,5 \%)$, UK (4,5\%), and Russia (4,5\%). It is noteworthy that Latin American and African countries are under-represented in geographical distribution. More studies about AC are required in countries like Brazil, South Africa, Bolivia, Peru, Ghana, and Ethiopia, among others. Furthermore, more investigation is necessary to understand the lack of studies in these regions.

Figure 5 - Number of papers published by geographic regions

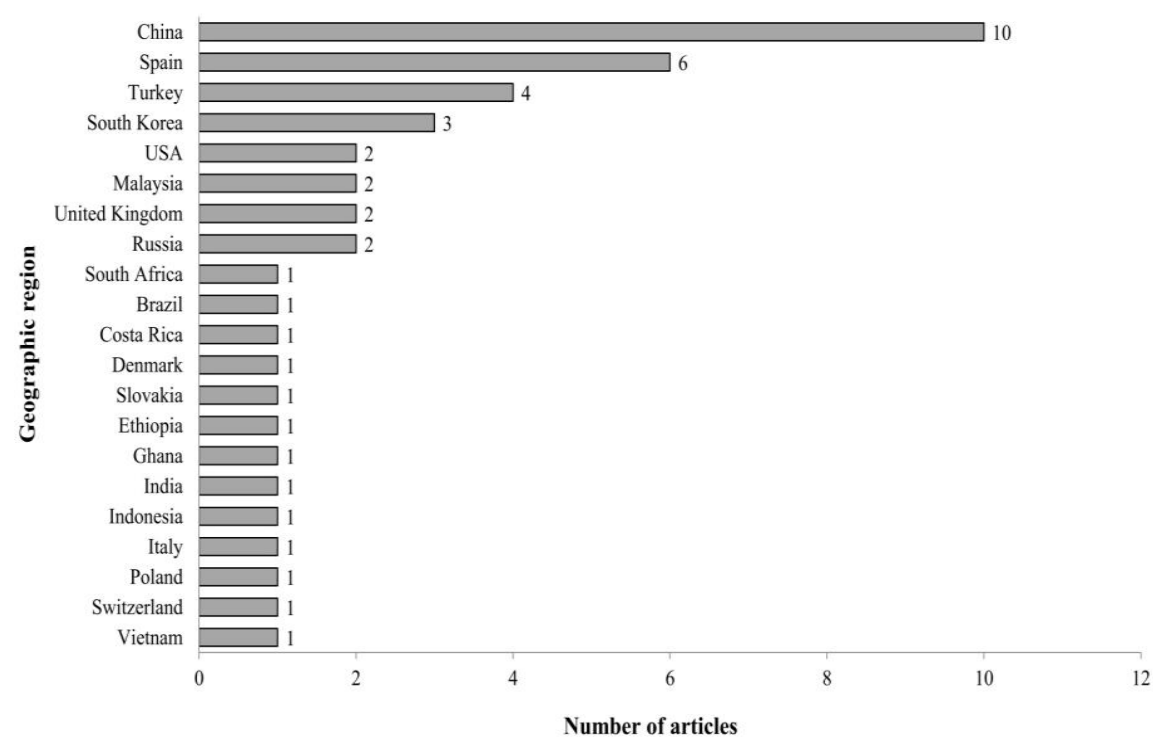

Source: the authors (2020). 


\subsection{Systemic analysis}

Table 4 shows an analysis of the focus and main results/contributions of the 11 articles that presented the study population at the national level, being of relevance for this study, since this one is emerging and developed countries.

Table 4 - Analysis of the focus and main results/contributions of the 11 articles that presented study population at national level.

\begin{tabular}{|c|c|c|c|}
\hline Author(s)/Year & Objective & Main results & $\begin{array}{c}\text { Limitations, contributitions } \\
\text { and/or originality } \\
\end{array}$ \\
\hline $\begin{array}{l}\text { Aldieri et al. } \\
(2018)\end{array}$ & $\begin{array}{l}\text { Exploring how firm- } \\
\text { level AC mediates the } \\
\text { relationship between } \\
\text { rent and spillovers of } \\
\text { R\&D on the one hand } \\
\text { and turnover in } \\
\text { another in three } \\
\text { economic areas } \\
\text { (Europe, Japan and the } \\
\text { USA). }\end{array}$ & $\begin{array}{l}\text { The empirical results suggest } \\
\text { that, at the same level of AC, } \\
\text { firms in economic areas closer } \\
\text { to the global technological } \\
\text { frontier tend to benefit more } \\
\text { from pure spillovers than from } \\
\text { rent spillovers. Conversely, } \\
\text { companies located in areas } \\
\text { that are not on the frontier of } \\
\text { technology seem to benefit } \\
\text { primarily from rental } \\
\text { spillovers that travel along the } \\
\text { supply chain. These results } \\
\text { suggest that AC changes with } \\
\text { the type of knowledge to } \\
\text { which they can be exposed. }\end{array}$ & $\begin{array}{l}\text { This article contributes to the } \\
\text { existing literature on AC in } \\
\text { several ways: first, it shows that } \\
\text { the nature of knowledge issues } \\
\text { and that companies specialize in } \\
\text { acquiring and processing specific } \\
\text { types of knowledge. Second, it } \\
\text { provides a potential explanation } \\
\text { as to why some companies } \\
\text { appear to benefit from some } \\
\text { types of spillovers over others } \\
\text { and relate these differences to the } \\
\text { characteristics of absorbed } \\
\text { knowledge. Finally, it provides } \\
\text { some suggestive evidence of how } \\
\text { the distance from the } \\
\text { technological frontier influences } \\
\text { the level of absorptive of the } \\
\text { firm's capacity. }\end{array}$ \\
\hline $\begin{array}{l}\text { Foster- } \\
\text { McGregor et al. } \\
(2017)\end{array}$ & $\begin{array}{l}\text { Focus on the role of } \\
\text { international R\&D } \\
\text { spillovers by trading } \\
\text { intermediary products } \\
\text { at the industry level } \\
\text { for a broad cross- } \\
\text { section of countries, as } \\
\text { well as investigating } \\
\text { the role of AC. }\end{array}$ & $\begin{array}{l}\text { It has been found that foreign } \\
\text { R\&D spillovers are stronger in } \\
\text { countries with higher AC } \\
\text { (measured by average years of } \\
\text { secondary schooling and R\&D } \\
\text { spending) and that they are } \\
\text { present and economically } \\
\text { important. }\end{array}$ & $\begin{array}{l}\text { The study does not include } \\
\text { countries at very low levels of } \\
\text { development, which is } \\
\text { characterized as a limitation of } \\
\text { work. The results also supported } \\
\text { studies that found that foreign } \\
\text { R\&D spillovers are stronger in } \\
\text { countries with higher AC. }\end{array}$ \\
\hline $\begin{array}{l}\text { Khordagui and } \\
\text { Saleh (2016) }\end{array}$ & $\begin{array}{l}\text { This paper examines } \\
\text { the role of human } \\
\text { capital as a factor of } \\
\text { AC for emerging } \\
\text { economies. }\end{array}$ & $\begin{array}{l}\text { The results refute the claim } \\
\text { that there are no significant } \\
\text { spillovers of FDI. FDI } \\
\text { spillovers are present in the } \\
\text { primary and tertiary sectors by } \\
\text { controlling the number of } \\
\text { years of schooling as a factor } \\
\text { of AC in sampled countries. } \\
\text { The results suggest that the } \\
\text { impact of FDI inflows in the } \\
\text { tertiary sector is almost equal } \\
\text { to that of the primary sector }\end{array}$ & $\begin{array}{l}\text { The contribution of this work is } \\
\text { that the primary, secondary and } \\
\text { tertiary sectors are examined and } \\
\text { the analysis is expanded to take } \\
\text { into account the main } \\
\text { components of the sectors. }\end{array}$ \\
\hline
\end{tabular}




\begin{tabular}{|c|c|}
\hline Author(s)/Year & Objective \\
\hline $\begin{array}{l}\text { Huebler et al. } \\
\text { (2016) }\end{array}$ & $\begin{array}{l}\text { Identify AC indicators } \\
\text { and their role in South- } \\
\text { North convergence } \\
\text { through a channel of } \\
\text { imported investment } \\
\text { goods. }\end{array}$ \\
\hline
\end{tabular}

Miguelez and

Moreno (2015)

Silajdzic and

Mehic (2015)
To assess the extent to which AC determines the impact of knowledge flows on regional innovation
To analyze the exogenous impact of FDI in economic growth, as well as to study the influence of technological and innovative capacities on growth performance among economies in

\section{FDI inflow.}

Regressions show that imports of machinery and other manufacturers incorporating advanced technologies are relatively strong. Importrelated productivity gains tend to induce South-North convergence of labor intensities, which is not fully robust to the different model specifications. A direct and trade-free South-North convergence effect was found by improving $\mathrm{AC}$ in our emerging economies, represented by the joint increase in several indicators. Even under the influence of AC, a couple of decades would be needed to halve the difference in labor intensities between emerging economies and major industrialized countries.

This article found strong support for the positive relationship between the geographical mobility of inventors' work and the intensity of regional innovation. In this context, it was also found that regions with high levels of AC are especially appropriate to make the most of the knowledge and information flows brought by the mobile work and cooperation networks. Both mechanisms (Mobility and Networks) can be used to access a wider range of skills, information, knowledge, inputs and skills external to the region.

In general, the results of the empirical analysis seem to support the hypothesis that FDI contributes to economic growth predominantly through knowledge spillovers and that the higher level of technological development adopted by government and business $R \& D$ expenditures is
Limitations, contributitions and/or originality

The findings of this article on AC indicators are relatively advanced for emerging economies.
The authors confirmed the results of previous work, in which both worker mobility and participation in research networks are critical means to transmit knowledge. The impact found is far from homogenous throughout the EU, with more developed regions achieving greater returns from the knowledge flows received by mobile inventors, while less advanced areas rely more heavily on networks.
The paper contributed to the recent literature, using a more reliable measure of FDI, while describing the character of FDI and related knowledge spillovers, as well as examining the importance of technological and innovative capabilities to explain growth performance among transition economies not 


\begin{tabular}{|c|c|c|c|}
\hline Author(s)/Year & Objective & Main results & $\begin{array}{c}\text { Limitations, contributitions } \\
\text { and/or originality }\end{array}$ \\
\hline & transition. & $\begin{array}{l}\text { associated with improved } \\
\text { performance among transition } \\
\text { economies. It has been found } \\
\text { that the positive impact of FDI } \\
\text { on economic growth is } \\
\text { associated with greater } \\
\text { capacity for knowledge and } \\
\text { efficiency. }\end{array}$ & previously studied. \\
\hline $\begin{array}{l}\text { Fracasso and } \\
\text { Marzetti (2014) }\end{array}$ & $\begin{array}{l}\text { To investigate how a } \\
\text { country's AC and } \\
\text { relative delay affect } \\
\text { the impact of } \\
\text { international R\&D } \\
\text { spillovers on the TFP. }\end{array}$ & $\begin{array}{l}\text { The results suggest that } \mathrm{AC} \text { is } \\
\text { positively associated with } \\
\text { international R\&D spillovers. } \\
\text { A good number of countries in } \\
\text { the sample exhibit a greater } \\
\text { elasticity than that estimated } \\
\text { by a linear panel model } \\
\text { (homogeneous parameter), } \\
\text { while South Korea, Portugal } \\
\text { and Ireland score worse than } \\
\text { all other countries. } \\
\text { Interestingly, but not } \\
\text { surprisingly, Greece, Italy and } \\
\text { Spain occupy an intermediate } \\
\text { position. }\end{array}$ & $\begin{array}{l}\text { The authors adopted a series of } \\
\text { updated econometric measures to } \\
\text { make robust inference in } \\
\text { unspecified forms of } \\
\text { heteroscedasticity and serial and } \\
\text { simultaneous correlation in the } \\
\text { data. The authors' knowledge is } \\
\text { the first time that this method is } \\
\text { used in an applied empirical } \\
\text { study. }\end{array}$ \\
\hline $\begin{array}{l}\text { Elmawazini } \\
(2014)\end{array}$ & $\begin{array}{l}\text { Contribute to the } \\
\text { empirical literature by } \\
\text { investigating the } \\
\text { hypothesis that } \\
\text { external direct } \\
\text { investment (FDI) } \\
\text { flows produced } \\
\text { positive productivity } \\
\text { spillovers for Gulf } \\
\text { Cooperation Council } \\
\text { (GCC) countries } \\
\text { during the period } 1995 \\
\text { to } 2011 \text {. }\end{array}$ & $\begin{array}{l}\text { The results show that FDI } \\
\text { flows produce weak and } \\
\text { negative productivity } \\
\text { spillovers for GCC countries } \\
\text { through their own or their } \\
\text { interaction with the host } \\
\text { country's AC. In addition, } \\
\text { empirical results show that } \\
\text { efficiency change (movements } \\
\text { to or away from the border) } \\
\text { and political stability are the } \\
\text { main factors affecting labor } \\
\text { productivity growth in GCC } \\
\text { countries. These results are } \\
\text { consistent with previous } \\
\text { studies of a single country on } \\
\text { technology transfer to } \\
\text { developing countries. }\end{array}$ & $\begin{array}{l}\text { The results say that these three } \\
\text { areas need further research. In the } \\
\text { first place, it would be interesting } \\
\text { to repeat the current study, } \\
\text { incorporating more developing } \\
\text { countries. Secondly, the link } \\
\text { between labor productivity and } \\
\text { income differences between the } \\
\text { GCC and the OECD countries } \\
\text { could be another document. } \\
\text { Thirdly, the human capital gap } \\
\text { between women and men, as } \\
\text { measured by average years of } \\
\text { secondary schooling, should also } \\
\text { be investigated as a gap between } \\
\text { the OECD countries and the } \\
\text { GCC. }\end{array}$ \\
\hline $\begin{array}{l}\text { Castillo et al. } \\
\text { (2011) }\end{array}$ & $\begin{array}{l}\text { This article examines } \\
\text { two sources of } \\
\text { spillovers of global } \\
\text { knowledge: external } \\
\text { direct investment } \\
\text { (FDI) and trade. }\end{array}$ & $\begin{array}{l}\text { The empirical analysis shows } \\
\text { positive effects of FDI and } \\
\text { trade productivity only when } \\
\text { the country has AC in terms of } \\
\text { R\&D; greater competition (in } \\
\text { terms of trade) is associated } \\
\text { with larger spillovers; and } \\
\text { countries with high R\&D } \\
\text { efforts gain more benefits } \\
\text { compared to those with less } \\
\text { R\&D effort. Commercial FDI } \\
\text { and spillovers are positive and } \\
\text { significant for scale efficiency } \\
\text { change and overall }\end{array}$ & $\begin{array}{l}\text { It is suggested that more general } \\
\text { policies should be pursued which } \\
\text { not only attract FDI but also } \\
\text { benefit national enterprises, for } \\
\text { example by building modern } \\
\text { infrastructures, enhancing and } \\
\text { strengthening institutions to } \\
\text { accelerate and sustain economic } \\
\text { growth. }\end{array}$ \\
\hline
\end{tabular}




\begin{tabular}{|c|c|c|c|}
\hline Author(s)/Year & Objective & Main results & $\begin{array}{c}\text { Limitations, contributitions } \\
\text { and/or originality }\end{array}$ \\
\hline & & $\begin{array}{l}\text { productivity factor change. } \\
\text { The empirical results show } \\
\text { that intra-country productivity } \\
\text { spillovers are present in Latin } \\
\text { American countries. Countries } \\
\text { with R\&D expenditures } \\
\text { receive more productivity } \\
\text { spillovers than those without } \\
\text { it. }\end{array}$ & \\
\hline Krammer (2010) & $\begin{array}{l}\text { To use the latest } \\
\text { developments in the } \\
\text { integration and } \\
\text { infrastructure } \\
\text { techniques of the panel } \\
\text { unit to unlink the } \\
\text { effects of international } \\
\text { spillovers through } \\
\text { trade and FDI inflows } \\
\text { into Total Factor } \\
\text { Productivity (TFP). }\end{array}$ & $\begin{array}{l}\text { The results confirm that trade } \\
\text { continues to be an important } \\
\text { source of productivity gains } \\
\text { through technological } \\
\text { spillovers to countries. } \\
\text { According to previous } \\
\text { findings, the significance of } \\
\text { these effects goes beyond their } \\
\text { national R\&D efforts, clearly } \\
\text { in the case of countries in } \\
\text { transition and to some extent } \\
\text { even developed ones. This } \\
\text { proves the massive impact of } \\
\text { international trade flows on } \\
\text { productivity and economic } \\
\text { growth around the world. FDI } \\
\text { has a significant but much } \\
\text { smaller impact, predominantly } \\
\text { in countries in transition, } \\
\text { where productivity differences } \\
\text { between domestic and foreign } \\
\text { firms are greater. Human } \\
\text { capital significantly impacts } \\
\text { countries' TFP levels, both } \\
\text { directly and as a production } \\
\text { factor, and indirectly as the } \\
\text { main determinant of their AC } \\
\text { over R\&D efforts. }\end{array}$ & $\begin{array}{l}\text { Current results contribute to the } \\
\text { existing literature by looking at } \\
27 \text { earlier Communist economies } \\
\text { and quantifying the importance of } \\
\text { the spillover channels of these } \\
\text { Eastern European and Central } \\
\text { Asian countries. New } \\
\text { improvements may consider the } \\
\text { use of data in the industry for a } \\
\text { better location of spillovers, } \\
\text { which tend to cluster in certain } \\
\text { industries. In addition, in the case } \\
\text { of countries in transition, their } \\
\text { industrial mix has changed } \\
\text { significantly throughout the } \\
\text { 1990s from industrialized } \\
\text { countries to a more balanced } \\
\text { economy in which the service } \\
\text { sector has grown tremendously. } \\
\text { Another interesting line of } \\
\text { research could explore the size } \\
\text { and dynamics of the indirect } \\
\text { effects of spillovers via FDI. }\end{array}$ \\
\hline Keller (2010) & $\begin{array}{l}\text { To examine how } \\
\text { international flows of } \\
\text { technological } \\
\text { knowledge affect } \\
\text { economic performance } \\
\text { in industries and } \\
\text { companies in different } \\
\text { countries. }\end{array}$ & $\begin{array}{l}\text { Evidence of technological } \\
\text { spillovers has been found } \\
\text { through international trade and } \\
\text { the activity of multinational } \\
\text { corporations. The analysis also } \\
\text { highlights the challenges for } \\
\text { future empirical research, as } \\
\text { well as the need for additional } \\
\text { data on technology and } \\
\text { innovation. }\end{array}$ & Not reported. \\
\hline
\end{tabular}

Source: the authors (2020).

The main topics covered in these articles (Table 4) refer to the search for the main AC indicators. The authors claim that the ability to attract FDI can bring immense benefits to a recipient country, as it is a source of knowledge and has been an essential element in the 
development strategies of some economies. The authors state that the effects of FDI on productivity growth are dependent on AC.

The obtained results have direct implications in the formulation of industrial policies to attract FDI, along with programs aiming to encourage the competitiveness of national industries, in order to increase their total productivity and their capacity to absorb knowledge.

Table 4 is important, as it shows the determinants of AC according to the selected literature. In this sense, Figure 6 illustrates the determinants of AC, which were selected based on the used variables, the type of measurement of $\mathrm{AC}$, the generation of spillovers, or cited by the articles as determinants of AC. We classified the determinants into four groups in order to analyze which factors have more proxies mentioned in the literature, as well as to maintain order. These groups are: Research (i.e., investments in research and education level); Organization (i.e., business technologies); Labor (i.e., human capital); Finance (i.e., financial management). We classified the overall group of studies (60 articles), including the nationallevel group (11 articles). Moreover, clustering was used to identify the weight that certain factors can offer to impact AC.

Figure 6 - Determinants of AC selected by the literature

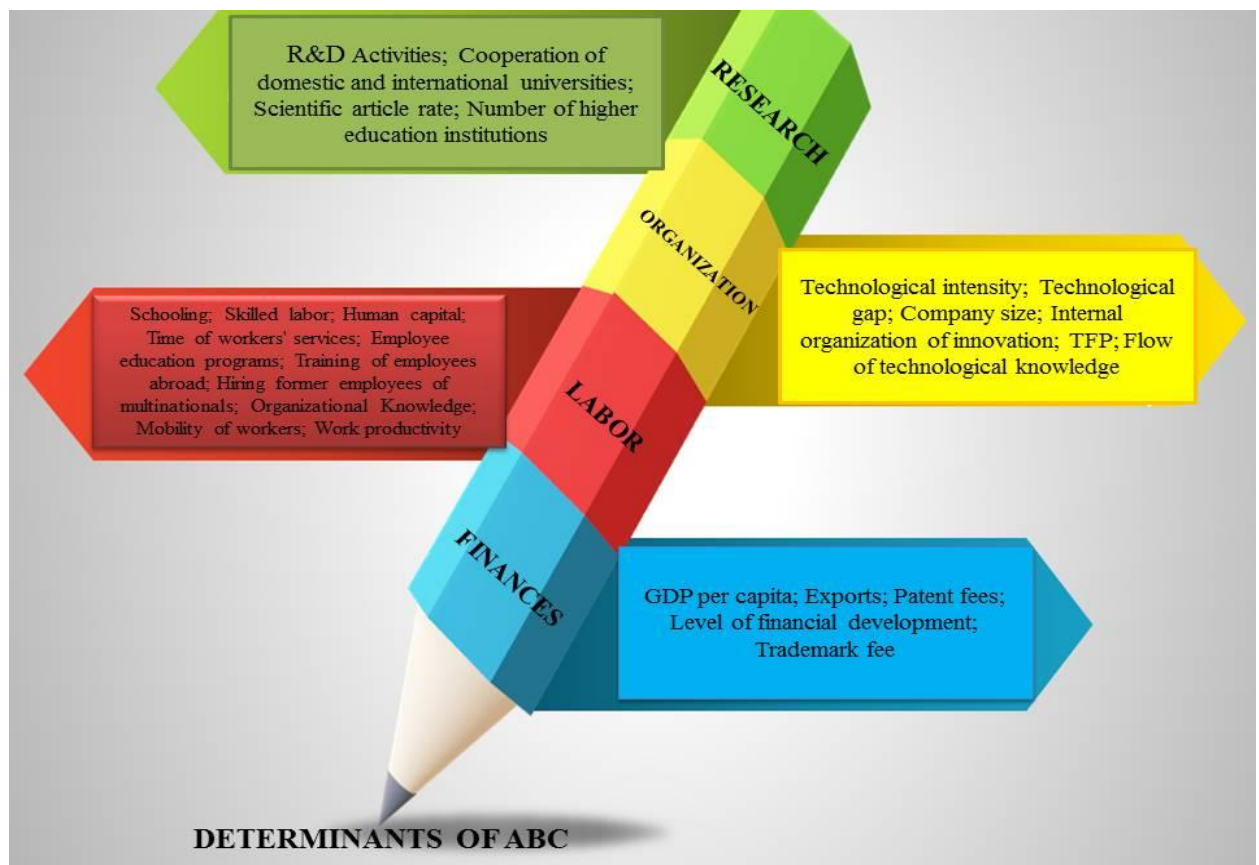

Source: the authors (2020).

Figure 7 shows the determinants for both developed and emerging countries. The main interest of this work is the selection of determinants of $\mathrm{AC}$ at the national level (developed 
and emerging countries). Thus, we separated the possible AC indicators only for the 11 articles mentioned above.

Figure 7 - Absorptive Capacity determinants selected by the literature - 11 articles (national level)

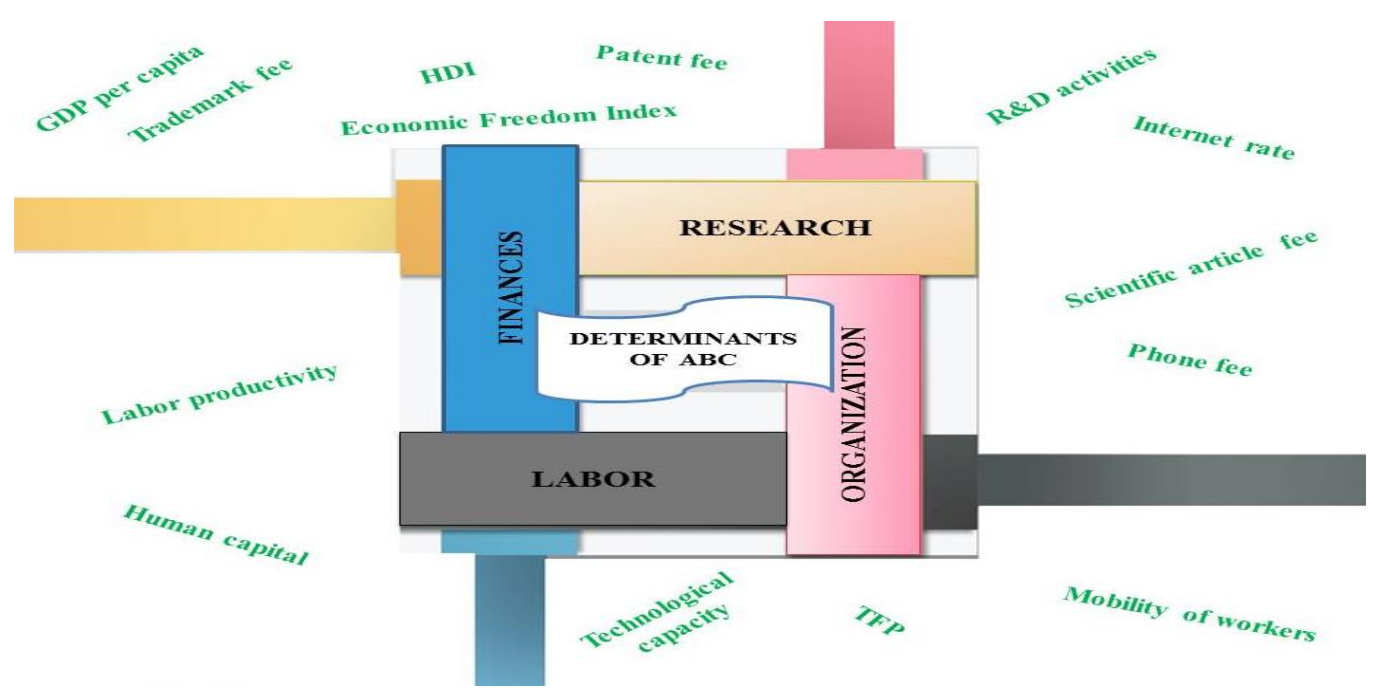

Source: the authors (2020).

Table 5 describes the definitions of these variables or means of measuring them according to the authors mentioned above.

Table 5 - Definitions of the variables according to the authors.

\begin{tabular}{|c|c|c|}
\hline $\begin{array}{l}\text { Author } \\
(\mathbf{s}) / \text { Year }\end{array}$ & $\begin{array}{c}\mathrm{AC} \\
\text { Determinants }\end{array}$ & Definition of authors \\
\hline $\begin{array}{l}\text { Aldieri } \text { et } \\
\text { al. }(2018)\end{array}$ & $\begin{array}{l}\text { R\&D activities } \\
\text { and number of } \\
\text { patents }\end{array}$ & $\begin{array}{l}\text { The stock of R\&D captures the cumulative nature of the learning process. } \\
\text { Another measure is the percentage of self-credits, that is, the percentage of } \\
\text { citations of patents issued by the same transferee. }\end{array}$ \\
\hline $\begin{array}{l}\text { Foster- } \\
\text { McGregor } \\
\text { et al. } \\
(2017)\end{array}$ & $\begin{array}{l}\text { Human capital } \\
\text { and } R \& D \\
\text { expenditure }\end{array}$ & $\begin{array}{l}\text { For the authors, the variables that capture the AC are information from the } \\
\text { Barro-Lee }{ }^{1} \text { dataset on the average years of secondary education in the } \\
\text { population. They followed the approach of Cohen \& Levinthal (1989) using } \\
\text { the registered R\&D value of the ANBERD }{ }^{2} \text { data set as an additional } \\
\text { indicator of AC. }\end{array}$ \\
\hline $\begin{array}{l}\text { Khordagui } \\
\text { and Saleh } \\
(2016)\end{array}$ & Human capital & $\begin{array}{l}\text { The human capital variable is measured by the average years of schooling } \\
\text { for adults over } 25 \text { years of age. }\end{array}$ \\
\hline
\end{tabular}

\footnotetext{
${ }^{1} \mathrm{http}: / / \mathrm{www}$. barrolee.com/. These data were used as a measure of absorptive capacity in similar studies.

${ }^{2}$ The OECD Business Development and Analysis (ANBERD) database presents annual R\&D expenditure by industry and was developed to provide analysts with comprehensive data on business R\&D expenditures. 139 GEPROS. Gestão da Produção, Operações e Sistemas, v.16, n. 2, p. 122 - 152, 2021
} 


\begin{tabular}{|c|c|c|}
\hline $\begin{array}{l}\text { Author } \\
\text { (s)/Year }\end{array}$ & $\begin{array}{c}\mathrm{AC} \\
\text { Determinants }\end{array}$ & Definition of authors \\
\hline $\begin{array}{l}\text { Huebler } \text { et } \\
\text { al. (2016) }\end{array}$ & $\begin{array}{l}\text { Participation of } \\
\text { highly qualified } \\
\text { labor force; Index } \\
\text { of economic } \\
\text { freedom; Tertiary } \\
\text { education rate; } \\
\text { Internet rate; } \\
\text { Telephone rate; } \\
\text { Scientific article } \\
\text { rate; Patent fees; } \\
\text { Trademark fee; } \\
\text { Participation of } \\
\text { the service sector; } \\
\text { High-tech } \\
\text { industry sharing }\end{array}$ & $\begin{array}{l}\text { Participation of highly qualified labor force - Percentage of highly skilled } \\
\text { working time in all working hours. The higher skills of workers are } \\
\text { commonly associated with higher education, including a better } \\
\text { understanding of technology. } \\
\text { Index of economic freedom - The index of economic freedom in the form of } \\
\text { registration. This index is the average of } 10 \text { sub-indices: commercial } \\
\text { freedom, commercial freedom, monetary freedom, government } \\
\text { size/spending, fiscal freedom, property rights, freedom of investment, } \\
\text { financial freedom, freedom from corruption and freedom of labor. } \\
\text { Tertiary education rate - Gross rate of tertiary education enrollment. } \\
\text { Internet rate - This is the number of Internet users per } 100 \text { people in the } \\
\text { population. } \\
\text { Phone Fee - These are the registration phone lines for } 100 \text { people of the } \\
\text { population. } \\
\text { Scientific article fee - This is the number of scientific and technical journals } \\
\text { journal entries within a specific country per capita. This measure indicates } \\
\text { the intensity of basic and, to some extent, applied research. } \\
\text { Patent Fee - This is the number of patent application registrations (by } \\
\text { nonresidents) in a specific country divided by the population of that country. } \\
\text { Trademark Fee - This is the trademark application registration number per } \\
\text { capita. Trademark applications are a more applied, industry-oriented } \\
\text { measure than patents. } \\
\text { High-tech industry sharing - This is the record output value of the high-tech } \\
\text { manufacturing industries divided by the total production value of the } \\
\text { manufacturing industry. The weight of the high-tech industry in the economy } \\
\text { is another indicator for pre-existing technologies and technological } \\
\text { capabilities that facilitate the adoption of new technologies. }\end{array}$ \\
\hline $\begin{array}{l}\text { Silajdzic } \\
\text { and Mehic } \\
(2015)\end{array}$ & R\&D Activities & $\begin{array}{l}\text { Measured as a share of R\&D expenditures by the business sector in the } \\
\text { country's GDP and by total government R\&D expenditures expressed as a } \\
\text { share in the country's GDP. }\end{array}$ \\
\hline $\begin{array}{l}\text { Miguelez } \\
\text { and } \\
\text { Moreno } \\
(2015)\end{array}$ & $\begin{array}{l}\text { R\&D Activities; } \\
\text { Mobility of } \\
\text { workers; Inventor } \\
\text { networks }\end{array}$ & $\begin{array}{l}\text { R\&D Activities: R\&D is not only a generator of foreground, but also a } \\
\text { means to improve the company's ability to assimilate and exploit existing } \\
\text { information. } \\
\text { Mobility of workers: Geographic mobility of knowledge workers. The } \\
\text { evidence supports the proposition about the role of AC in the assimilation of } \\
\text { knowledge flows from labor mobility. } \\
\text { Inventor Networks: Interregional Technology Networks. The economically } \\
\text { least developed regions are those which benefit most from the geographical } \\
\text { spread of knowledge through technological cooperation networks. }\end{array}$ \\
\hline $\begin{array}{l}\text { Fracasso } \\
\text { and } \\
\text { Marzetti } \\
(2014)\end{array}$ & $\begin{array}{l}\text { Human capital } \\
\text { and } R \& D \\
\text { activities }\end{array}$ & $\begin{array}{l}\text { Human capital: Average years of schooling. } \\
\text { R\&D activities: The results suggest that AC is positively associated with } \\
\text { international repercussions of R\&D. }\end{array}$ \\
\hline
\end{tabular}




\begin{tabular}{|c|c|c|}
\hline $\begin{array}{l}\text { Author } \\
\text { (s)/Year }\end{array}$ & $\begin{array}{c}\mathrm{AC} \\
\text { Determinants }\end{array}$ & Definition of authors \\
\hline $\begin{array}{l}\text { Elmawazini } \\
(2014)\end{array}$ & $\begin{array}{l}\text { GDP per capita, } \\
\text { labor } \\
\text { productivity, TFP, } \\
\text { human capital, } \\
\text { Technological } \\
\text { capacity, Human } \\
\text { Development } \\
\text { Index (HDI) }\end{array}$ & $\begin{array}{l}\text { GDP per capita: Developed countries are expected to have a higher level of } \\
\text { human capital and therefore benefit more from FDI than developing } \\
\text { countries. } \\
\text { Labor productivity: Foreign presence has a significant positive effect on } \\
\text { labor productivity. } \\
\text { TFP: There are negative impacts on the Total Factor Productivity resulting } \\
\text { from the allocation of FDI in regions that do not have minimum levels of } \\
\text { AC. AC is defined as the TFP level in the previous period divided by the } \\
\text { maximum TFP level in the industry. } \\
\text { Human capital: Measured by average years of schooling. } \\
\text { Technology capability: Measured by royalty receipts and license fees. } \\
\text { Human Development Index (HDI): Studies on the effects of FDI have } \\
\text { generally used human capital, represented by the average years of schooling, } \\
\text { as a measure of the AC of the host countries. Above all, it is argued that the } \\
\text { HDI best captures the AC of the host country. Skills can be acquired not only } \\
\text { through formal education, but also through training and work experience; } \\
\text { and this acquisition of skills is further supported by improvements in other } \\
\text { social indicators. }\end{array}$ \\
\hline $\begin{array}{l}\text { Castillo et } \\
\text { al. }(2011)\end{array}$ & $\begin{array}{l}\text { Activities in } \\
\text { R\&D, human } \\
\text { capital }\end{array}$ & $\begin{array}{l}\text { R\&D Activities: The presence of productivity spillovers depends on the } \\
\text { investment efforts of local firms in R\&D activities. They play an important } \\
\text { role in the transfer of knowledge, in addition to its role as a means of } \\
\text { innovation. } \\
\text { Human capital: There is evidence that the positive impacts of the } \\
\text { development of FDI flows depend on the high level of human capital and } \\
\text { hence on the existence of "good" infrastructure in host countries. }\end{array}$ \\
\hline $\begin{array}{l}\text { Krammer } \\
(2010)\end{array}$ & $\begin{array}{l}\text { Human capital; } \\
\text { R\&D activities }\end{array}$ & $\begin{array}{l}\text { Both human capital and domestic R\&D efforts increase a country's AC and } \\
\text { contribute to increased productivity. } \\
\text { Human capital - average years of schooling among men over } 25 \text { years of age. }\end{array}$ \\
\hline $\begin{array}{l}\text { Keller } \\
(2010)\end{array}$ & R\&D Activities & $\begin{array}{l}\text { The high level of R\&D is consistent with the idea that countries need to } \\
\text { develop AC to be able to produce spillover of productivity from local firms. }\end{array}$ \\
\hline
\end{tabular}

Some variables did not have their measurements defined by the authors.

Source: the authors (2020).

We found that R\&D and Human Capital are considered the most frequent determinants of AC. This finding corroborates with the literature as multinational companies play an essential role in economic development by increasing their $R \& D$ efforts, especially in developing countries. Cantwell (1995) presents evidence that the internationalization of R\&D was pioneered by companies leading their respective fields. In this sense, $R \& D$ internationalization is a product of capital internationalization (i.e., foreign investments), and is a response to the need to adapt products, processes and materials in developing regions, which usually lack this knowledge and depends on external sources.

R\&D activities can be measured through investments in the area, workforce training or professionals linked to this type of activity. Human capital can be measured through average years of study or by the level of knowledge diffused in the region (e.g., the number of people 
with higher education) (MUROVEC; PRODAN, 2009; JIMÉNEZ-BARRIONUEVO et al., 2011; SHENBAROW, 2014; LICHTENTHALER, 2016).

R\&D investments enable innovations and, at the same time, allow the internalization of knowledge produced by other sources, especially foreign companies. Companies' skills to recognize and assimilate new knowledge are primarily due to their workers' capabilities (MUROVEC; PRODAN, 2009; JIMÉNEZ-BARRIONUEVO et al., 2011; SHENBAROW, 2014; LICHTENTHALER, 2016).

Furthermore, human capital is one of the most important determinants of AC. This finding is in line with the literature since Murovec and Prodan (2009) showed that companies' skills in recognizing and assimilating new knowledge derive, to a large extent, from the individual capabilities of their workers.. Moreover, according to Castillo et al. (2011) human capital is important because there is evidence that the positive impacts of the development of FDI flows depend on the high level of human capital. Miguelez and Moreno (2015) comment on the positive role of $\mathrm{AC}$ in assimilating knowledge flows from workers' geographical mobility.

Therefore, the more training and education an employee receives, the greater will be his or her ability to assimilate and use new knowledge. Because AC depends on employees, the level of education, experience and training has a positive influence on the level of AC in companies.

It is noteworthy that $\mathrm{R} \& \mathrm{D}$ and human capital are important tools to boost absorptive capacity and, consequently, economic development. In this sense, policymakers must create mechanisms to encourage new $R \& D$ investments. An adequate macroeconomic environment might attract multinational companies to bring new investments to the host economy. Also, educational policies, such as formal education and professional training, could be important initiatives to increase the local human capital.

Tertiary education can be considered a proxy for human capital, and it does not represent the variation of quality between education systems worldwide. Internet rate and technological capacity appear as determinants of AC in some studies, but they require more investigation to reveal how these variables are linked with AC.

The Human Development Index (HDI) was used to determine AC in Elmawazini (2014). According to this author, the HDI affects AC because skills can be acquired through training and professional experience, and this acquisition of skills is further supported by 
improvements in other social indicators. Health and economic conditions can affect productivity and technology diffusion, providing an environment conducive to innovation. Thus, the countries that are able to absorb more knowledge are also those that are able to achieve higher life expectancy, higher education level and higher incomes. Regarding the determinant Index of Economic Freedom (IEF), cited by Huebler et al. (2016), it can be said that in economically free societies, governments allow labor, capital and goods to move freely, and this freedom to do business, including in technology-oriented areas, facilitates innovation and adoption of new technologies. According to Elmawazini (2014), productivity gains will be linked to the Absorptive Capacity, since innovative producers are more receptive to new technologies and, thus, are able to maximize gains and reduce costs. Thus, the TFP becomes a fundamental and determining factor for the increase in CA in developed or emerging and developing countries.

\section{CONCLUDING REMARKS}

This study started from the hypothesis that AC has determinants that can influence countries' productivity through external investments. These determinants help measure the acquisition, assimilation, transformation, and exploitation of knowledge.

The presented hypothesis assures that FDI contributes to economic growth predominantly through knowledge spillovers and that the higher level of technological development adopted by government and business $\mathrm{R} \& \mathrm{D}$ expenditures is associated with improved growth performance among transition economies and that the positive impact of FDI on economic growth is associated with greater capacity for knowledge and efficiency.

Thus, the performed systematic literature review selected 14 determinants for AC, with $R \& D$ activities and human capital being the most cited in the literature. It can be stated that the presence of productivity spillovers depends on the investment efforts of local companies in R\&D activities. They play an essential role in the transfer of knowledge and its role as a means of innovation. There is evidence that the positive impacts of FDI flow development depend on the high level of human capital and the existence of "good" infrastructure in host countries.

This study contributes to organizing the literature about the determinants of AC. However, this study presents some limitations. First, we did not use a large number of 
keywords, which could be attached by future studies. Second, we analyzed studies written in English, which does not bring works written in Spanish, Portuguese, Chinese, and other important languages for developing countries. Third, we did not analyze in-depth research methods. Future studies could investigate which empirical methods are adequate to measure AC. Finally, future studies might analyze AC in under-represented geographic areas, which is crucial for policy recommendations in Latin American and African countries.

Finally, identifying the determinants of AC helps achieve goals before a possible FDI attraction policy. This analysis brings tools to enhance positive productivity spillovers and avoid negative spillovers related to competition for the domestic industry.

\section{References}

AFONSO, M. H. F.; SOUZA, J. V. D.; ENSSLIN, S. R.; ENSSLIN, L. Como construir conhecimento sobre o tema de pesquisa? Aplicação do processo Proknow-C na busca de literatura sobre avaliação do desenvolvimento sustentável. Revista de Gestão Social e Ambiental, v.5, n.2, p. 47-62, 2012.

ALDIERI, L.; SENA, V.; VINCI, C. P. Domestic R\&D spillovers and absorptive capacity: Some evidence for US, Europe and Japan. International Journal of Production Economics, v.198, p. 38-49, 2018.

AHMED, E. M. Are the FDI inflow spillover effects on Malaysia's economic growth input driven?. Economic Modelling, v.29, n.04, p.1498-1504, 2012.

AMOROSO, S.; MÜLLER, B. The short-run effects of knowledge intensive greenfield FDI on new domestic entry. Journal of Technology Transfer, p.01-22, 2017.

ANWAR, S.; NGUYEN, L. P. Is foreign direct investment productive? A case study of the regions of Vietnam. Journal of Business Research, v.67, n.07, p.1376-1387, 2014.

AUGIER, P.; CADOT, O.; DOVIS, M. Imports and TFP at the firm level: the role of absorptive capacity. Canadian Journal of Economics-Revue Canadienne D Economique, v.46, n.03, p.956-981, 2013.

BARRIOS, S.; STROBL, E. Foreign direct investment and productivity spillovers: Evidence from the Spanish experience. Weltwirtschaftliches Archiv, v. 138, n.3, p. 459-481, 2002.

BARRO, R, J.; SALA-I-MARTIN, X. Technological diffusion, convergence, and growth. The Journal of Economic Growth, v. 2, p. 1-27, 1997. 
BEHERA, S. R. Regional foreign direct investment and technology spillover: evidence across different clusters in India. Economics of Innovation and New Technology, v.26, n.07, p.596-620, 2017.

BLOCH, C. R\&D spillovers and productivity: An analysis of geographical and technological dimensions. Economics of Innovation and New Technology, v.22, n.05, p.447-460, 2013.

BRUHN, N. C. P.; CALEGARIO, C. L. L. Productivity spillovers from foreign direct investment in the Brazilian processing industry. BAR - Brazilian Administration Review, v.11, n.01, p.22-46, 2014.

CANTWELL, J. The globalization of technology: what remains of the product cycle model? Cambridge Journal of Economics, v.19, p.155-174, 1995.

CARAGLIU, A.; DEL BO, C. Determinants of spatial knowledge spillovers in Italian provinces. Socio-Economic Planning Sciences, v.45, n.01, p.28-37, 2011.

CARDOSO, T. L.; ENSSLIN, S. R.; DIAS, J. Avaliação de desempenho da sustentabilidade financeira da Universidade do Mindelo (Cabo Verde): um modelo multicritério construtivista. Revista Eletrônica de Estratégia \& Negócios, v.9, n.2, p. 234-264, 2016.

CASTILLO, L. L.; SALEM, D. S.; GUASCH, J. L. Innovative and Absorptive Capacity of International Knowledge: An Empirical Analysis of Productivity Sources in Latin American Countries. Latin American Business Review, v.12, n. 4, p. 309-335, 2011.

CAVUSGIL, T. S.; KNIGHT, G. A, RIESENBERGER, J. R.; BRITTO, R. P. Negócios Internacionais; estratégia, gestão e novas realidades. São Paulo: Pearson, 2010.

COHEN, W. M.; LEVINTHAL, D. A. Absorptive capacity: a new perspective on learning and innovation. Administrative Science Quarterly, 35(129), 1990.

COHEN, W.; LEVINTHAL, D. Innovation and learning: the two faces of R\&D. Economic Journal, v. 99, n.397, p. 569-596, 1989.

CRESWELL, J. W. Projeto de pesquisa: métodos qualitativo, quantitativo e misto. 2.ed. Porto Alegre: Artmed, 2007.

DENYER, D.; TRANFELD, D. Producing a Systematic Review. In: BUCHANAN, D.; BRYMAN, A. The Sage Handbook of Organizational Research Methods, p.671-689. London: Sage, 2009.

DOGAN, E.; WONG, K. N.; YAP, M. M. C. Vertical and Horizontal Spillovers from Foreign Direct Investment: Evidence from Malaysian Manufacturing. Asian Economic Papers, v.16, n.03, p.158-183, 2017.

DUTRA, A.; RIPOLL-FELIU, V. M.; FILLOL, A. G.; ENSSLIN, S. R.; ENSSLIN, L. The construction of knowledge from the scientific literature about the theme seaport performance 
evaluation. International Journal of Productivity and Performance Management, v. 64, n.2, p. 243-269, 2015.

ELMAWAZINI, K. FDI Spillovers, Efficiency Change and Host Country Labor Productivity: Evidence from GCC Countries. Atlantic Economic Journal, v.42, n.4, p. 399-411, 2014.

ENSSLIN, L.; GIFFHORN, E.; ENSSLIN, S. R.; PETRI, S. M.; VIANNA, W. B. Avaliação do desempenho de empresas terceirizadas com o uso da metodologia multicritério de apoio à decisão-construtivista. Pesquisa operacional, v.30, n. 1, p. 125-152, 2010.

FATIMA, S. T. Absorptive Capacity and FDI Spillovers: Evidence from Quantile Regressions. International Trade Journal, v.31, n.04, p.360-385, 2017.

FOSTER-MCGREGOR, N.; ISAKSSON, A.; KAULICH, F. Importing, Productivity and Absorptive Capacity in Sub-Saharan African Manufacturing and Services Firms. Open Economies Review, v.27, n.01, p.87-117, 2016.

FOSTER-MCGREGOR, N.; PÖSCHL, J.; STEHRER, R. The importance of absorptive capacities: productivity effects of international $R \& D$ spillovers through intermediate inputs. Economics of Innovation and New Technology, v.26, n.8, p.719-733, 2017.

FRACASSO, A.; VITTUCCI MARZETTI, G. International R\&D Spillovers, Absorptive Capacity and Relative Backwardness: A Panel Smooth Transition Regression Model. International Economic Journal, v. 28, n.1, p. 137-160, 2014.

GERSCHEWSKI, S. Do local firms benefit from foreign direct investment? An analysis of spillover effects in developing countries. Asian Social Science, v.09, n.04, p.67-76, 2013.

GIRMA, S. Absorptive Capacity and Productivity Spillovers from FDI: A Threshold Regression Analysis. Oxford Bulletin of Economics and Statistics, v.67, n. 3, p. 281-306, 2005.

GREENER, S. Business research methods. London: BookBoon, 2008.

GRIMPE, C.; SOFKA, W. Search patterns and absorptive capacity: Low- and high technology sectors in European countries. Research Policy, v.38, n.3, p. 495-506, 2008.

GU, K.; WANG, H. R\&D, Absorptive Capacity, and Technology Spillover via FDI - An Empirical Study based on Chinese Manufacturing Industries. 6th Euro-Asia Conference on Environment and Corporate Social Responsibility, p.91, 2010.

HAMIDA, L. B. Are there regional spillovers from FDI in the Swiss manufacturing industry? International Business Review, v.22, n.04, p.754-769, 2013.

HIGOACUTEN, D. A.; VASILAKOS, N. Foreign Direct Investment Spillovers: Evidence from the British Retail Sector. World Economy, v.34, n.04, p.642-666, 2011. 
HU, H.; LI, X. The Spillover Effect of R\&D, HK to Zhejiang Urban Innovation: An Empirical Study Based on Absorptive Capacity. 2nd International Symposium on Public Human Resource Management. Zhejiang Gongshan Univ, Sch Business Adm, Hangzhou, p. 155-161, 2013.

HUANG, Y.; ZHANG, Y. How does outward foreign direct investment enhance firm productivity? A heterogeneous empirical analysis from Chinese manufacturing. China Economic Review, v.44, p.1-15, 2017.

HUEBLER, M.; GLAS, A.; NUNNENKAMP, P. Indicators of Absorptive Capacity and Import-induced South-North Convergence in Labour Intensities. World Economy, v.39, n.11, p. 1756-1791, 2016.

IWASAKI, I.; SUGANUMA, K. Foreign direct investment and regional economic development in Russia: an econometric assessment. Economic Change and Restructuring, v.48. n.03-04, p.209-255, 2015.

JACOBS, E. J.; ZÁMBORSKÝ, P.; SBAI, E. Mutual Productivity Spillovers in Slovakia: Absorptive Capacity, the Technology Gap, and Nonlinear Effects. Eastern European Economics, v.55, n.04, p.291-323, 2017.

JEON, J.; HONG, S.; OHM, J.; YANG, T. Causal relationships among technology acquisition, absorptive capacity, and innovation performance: Evidence from the pharmaceutical industry. PLoS ONE, v.10, n.07, 2015.

JIMÉNEZ-BARRIONUEVO, M. M.; GARCÍA-MORALES, V. J.; MOLINA， L. M. Validation of an instrument to measure absorptive capacity. Technovation, v.31, n.5/6, p.190-202, 2011.

KELLER, W. International trade, foreign direct investment, and technology spillovers. Handbook of the Economics of Innovation, v.2, n.1, p. 793-829, 2010.

KHORDAGUI, N.; SALEH, G. Absorptive capacity factors that mediate foreign direct investment spillovers: A sector-level analysis from emerging economies. International Journal of Business and Globalisation, v.16, n. 2, p. 188-201, 2016.

KIM, M. Productivity spillovers from FDI and the role of domestic firm's absorptive capacity in South Korean manufacturing industries. Empirical Economics, v.50, n.04, p.1647, 2016.

KIM, C. H.; PARK, B. I. Knowledge spillovers from inward foreign direct investment in the banking industry: An empirical examination in Korea. Management Decision, v.55, n.09, p.2053-2072, 2017.

KING, A.; LAKHANI, K. R. The Contingent Effect of Absorptive Capacity: An Open Innovation Analysis. Working Knowledge - Business Research for Business Leaders, 134, 2011. 
KÖYMEN ÖZER, S.; SAYEK BÖKE, S. The Characteristics of Domestic Firms: Materializing Productivity Spillovers from FDI. Emerging Markets Finance and Trade, v.53, n.11, p.2562-2584, 2017.

KRAMMER, S. M. S. International R\&D spillovers in emerging markets: The impact of trade and foreign direct investment. The Journal of International Trade \& Economic Development, v. 19, n. 4, 2010.

LACERDA, R. T. O.; ENSSLIN, L.; ENSSLIN, S. R. Uma análise bibliométrica da literatura sobre estratégia e avaliação de desempenho. Gestão \& Produção, v. 19, n. 1, p. 59-78, 2012.

LAPAN, H.; BARDHAN, P. Localized Technical Progress and Transfer of Technology and Economic Development. Journal of Economic Theory, v.6, p.585-595, 1973.

LEIVA, J. C.; RODRÍGUEZ ALVAREZ, J. A.; MONGE GONZÁLEZ, R. Effects of hiring former employees of multinationals in the absorptive capacity of local firms. Contaduria $\mathbf{y}$ Administracion, v.62, n.02, p.670-682, 2017.

LEW, Y. K.; LIU, Y. The contribution of inward FDI to Chinese regional innovation: The moderating effect of absorptive capacity on knowledge spillover. European Journal of International Management, v.10, n.03, p.284-313, 2016.

LIAO, H.; LIU, X.; WANG, C. Knowledge spillovers, absorptive capacity and total factor productivity in China's manufacturing firms. International Review of Applied Economics, v.26, n.04, p.533-547, 2012.

LIANG, F. H. Does foreign direct investment improve the productivity of domestic firms? Technology spillovers, industry linkages, and firm capabilities. Research Policy, v.46, n.01, p.138-159, 2017.

LICHTENTHALER, U. Determinants of absorptive capacity: the value of technology and market orientation for external knowledge acquisition. Journal of Business and Industrial Marketing, v.31, n.05, p.600-610, 2016.

LI-MING, X.; RUI, J.; RUI, J. Productivity Spillovers from FDI, Absorptive Capacity and Self-innovation Capabilities of Resource Area: Evidence from 1992-2013 in Shanxi, China. Science, Technology and Society, v.21, n.02, p.149-180, 2016.

LOPEZ-GARCIA, P.; MONTERO, J. M. Spillovers and absorptive capacity in the decision to innovate of Spanish firms: The role of human capital. Economics of Innovation and New Technology, v.21, n.07, p.589-612, 2012.

LYCHAGIN, S. Spillovers, absorptive capacity and agglomeration. Journal of Urban Economics, v.96, p.17-35, 2016. 
MALAGUERRA, N. M. P. A Importância da Capacidade de Absorção e Inovação para o Crescimento Económico. Coimbra, Dissertação (Mestrado) - Faculdade de Economia, Universidade de Coimbra, 2014.

MARCIN, K. How does FDI infow affect productivity of domestic firms? The role of horizontal and vertical spillovers, absorptive capacity and competition. Journal of International Trade and Economic Development, v. 17, n. 1, p. 155-173, 2008.

MIGUELEZ, E.; MORENO, E. Knowledge flows and the absorptive capacity of regions. Research Policy, v. 44, n. 4, p. 833-848, 2015.

MUROVEC, N., PRODAN, I. Absorptive capacity, its determinants, and influence on innovation output: Cross-cultural validation of the structural model. Technovation, v.29, n.12, pp. 859-872, 2009.

NUERNBERG, E. G.; ENSSLIN, S. R.; CARDOSO, T. L.; VALMORBIDA, S. M. Gestão Universitária: identificação e análise dos indicadores utilizados na literatura. Revista Contemporânea de Economia e Gestão, v. 14, n. 3, 2016.

OKAFOR, L. E.; BHATTACHARYA, M.; BLOCH, H. Imported Intermediates, Absorptive Capacity and Productivity: Evidence from Ghanaian Manufacturing Firms. World Economy, v.40, n.02, p.369-392, 2017.

OZER, S.K.; BOKE, S. S. The Characteristics of Domestic Firms: Materializing Productivity Spillovers from FDI. Emerging Markets Finance And Trade, v.53, n.11, p.2562-2584, 2017.

PARK, B. I.; KIM, C. H.; CHOI, S. B. Knowledge spillovers through inward FDI in emerging markets: An empirical examination in the supermarket industry. European Journal of International Management, v.10, n.03, p.314-342, 2016.

QI, J.; ZHENG, Y.; LAURENCESON, J.; LI, H. Productivity spillovers from FDI in China: Regional differences and threshold effects. China and World Economy, v.17, n.04, p.18-35, 2009.

QIU, S.; LIU, X.; GAO, T. Do emerging countries prefer local knowledge or distant knowledge? Spillover effect of university collaborations on local firms. Research Policy, v.46, n.07, p.1299-1311, 2017.

REIM, W.; PARIDA, V. E.; ÖRTQVIST, D. Product - Service Systems (PSS) business models and tactis - s systematic literature review. Journal of Cleaner Production, v. 97, n. 1, p. 61-75, 2015.

RICHARDSON, R. J.; PERES, J. A. Pesquisa social: métodos e técnicas. 3.ed. São Paulo: Atlas, 1999. 
ROJEC, M.; KNELL, M. Why is there a lack of evidence on knowledge spillovers from foreign direct investment? Journal of Economic Surveys, v.32, n.3, 2017.

SÁNCHEZ-SELLERO， P.; ROSELL-MARTÍNEZ， J.; GARCÍA-VÁZQUEZ， J. M. Absorptive capacity from foreign direct investment in Spanish manufacturing firms. International Business Review, v.23, n.02, p.429-439, 2014.

SANCHEZ-SELLERO, P.; ROSELL-MARTINEZ, J.; MANUEL GARCIA-VAZQUEZ, J. Innovation as a driver of absorptive capacity from foreign direct investment in Spanish manufacturing firms. 2nd Annual International Conference on Leadership, Technology and Innovation Management. Local: Beykent Univ, Taksim Campus, Istanbul, v.75, p. 236$245,2013$.

SARI, D. W.; KHALIFAH, N. A.; SUYANTO, S.. The spillover effects of foreign direct investment on the firms' productivity performances. Journal of Productivity Analysis, v. 46, n. 2-3, p. 199-233, 2016.

SEYOUM, M.; WU, R.; YANG, L. Technology spillovers from Chinese outward direct investment: The case of Ethiopia. China Economic Review, v.33, p.35-49, 2015.

SHENBAROW, A. A. Absorptive capacity and organizational determinants: Evidence of associations. International Conference on Engineering, Technology and Innovation: Engineering Responsible Innovation in Products and Services, ICE, p. 6871600, 2014.

SILAJDZIC, S.; MEHIC, E. Knowledge spillovers, absorptive capacities and the impact of FDI on economic growth: empirical evidence from transition economies. World Conference on Technology, Innovation and Entrepreneurship, p.614-623, 2015.

SIVALOGATHASAN, V.; WU, X. The effect of foreign direct investment on innovation in south asian emerging markets. Global Business and Organizational Excellence, v.33, n.03, p.63-76, 2014.

SILVA, R. V.; ENSSLIN, S. R.; RIPOLL-FELIU, V. M.; SOLER, C. C. E-government and Public Accounting Information: Bibliometric and Systemic Analysis. International Research Journal of Finance and Economics, v. 1, n. 122, p. 76-91, 2014.

SMITH, N.; THOMAS, E. Regional conditions and innovation in Russia: the impact of foreign direct investment and absorptive capacity. Regional Studies, v.51, n.09, p.1412-1428, 2017.

SMEETS, R. Collecting the pieces of the FDI knowledge spillovers puzzle. World Bank Research Observer, v. 23, n. 2, p. 107-138, 2008.

TANG, Y.; ZHANG, K. H. Absorptive capacity and benefits from FDI: Evidence from Chinese manufactured exports. International Review of Economics \& Finance, v.42, p.423429, 2016. 
TAKII, S. Productivity spillovers and characteristic of foreign multinational plants in Indonesian manufactuiring. Journal of Development Economics, v. 76, n. 2, p. 521-542, 2005 .

TODOROVA, G.; DURISIN, B. Absorptive Capacity: Valuing a Reconceptualization. Academy of Management Review, v. 32, n.3, p. 774-786, 2007.

UBEDA, F.; PÉREZ, H. F. Absorptive Capacity and Geographical Distance Two Mediating Factors of FDI Spillovers: a Threshold Regression Analysis for Spanish Firms. Journal of Industry, Competition and Trade, v.17,n.01, p.1-28, 2017.

ZAHRA, S. A.; GEORGE, G. Absorptive Capacity: A Review, Reconceptualization, and Extension. The Academy of Management Review, v. 27, n.2, p. 185-203, 2002.

ZHANG, Y.; LI, H.; LI, Y.; ZHOU, L. A. FDI spillovers in an emerging market: The role of foreign firms' country origin diversity and domestic firms' absorptive capacity. Strategic Management Journal, v.31, n. 9, p. 969-989, 2010. 


\section{APPENDIX A - SYSTEMATIC REVIEW PROTOCOL}

Objective: To analyze the determinants of Absorptive Capacity from External Direct Investment Formulation of the research question: What are the determinants of Absorptive Capacity? Items related to the scope and specificities of the research question:

- Control: collection of articles and other works raised and related in bibliographic reviews of master's dissertations, doctoral theses and books related to the research area.

- Population: Countries / states / regions / cities

Strategies for searching and selecting primary studies:

The resources and strategies for research and selection of studies were defined and selected based on four fundamental items:

- Search sources: database (Scopus / Web of Science)

- English language

- Keywords: Knowledge Spillover AND Absorptive Capacity

- Date of publication: No lower or upper limits were established for the date of publication of articles.

Criteria and procedures for selection of studies:

\section{Inclusion criteria}

(I) Did the article consider the absorptive capacity as one of the variables that impact the productivity of units?

(II) Does the article consider that the generation of externalities with FDI inflows depends on the capacity of absorptive?

(III) Publication in English.

\section{Exclusion Criteria}

(I) The article does not focus on the generation of productivity spillovers

(II) The article does not consider the absorptive capacity important for the productivity of units

\section{Selection process of studies}

\section{Preliminary selection process}

Articles will be selected by reading the abstracts.

\section{Final selection process}

The articles selected by the abstract will be reviewed according to the inclusion and exclusion criteria. 